\title{
KINERJA PEMANTAUAN PROSES MESIN SORTIR BUNGKUS PERMEN MELALUI SCADA - IMAGE PROCESSING
}

\author{
Madeleine $^{1}$, Imam Halimi ${ }^{2}$ dan Septina Indrayani \\ 1,2,3 Teknik Elektro, Teknik Otomasi Listrik Industri, Politeknik Negeri Jakarta, Jl. Prof. DR. G.A. \\ Siwabessy, Kukusan, Kecamatan Beji, Kota Depok, 16424, Indonesia \\ E-mail:madeleinepdgn@gmail.com ${ }^{1}$
}

\begin{abstract}
In the development of the production process in the era of the industrial revolution 4.0, speed, accuracy, consistency, and accuracy are needed. Therefore we need a system that can monitor, control, and acquire the required data from a production process, this system is called SCADA. In this article, SCADA programming is made with Vijeo Citect software to monitor and control the image processing based candy wrapper sorting machine. This image processing-based sorting machine functions to sort workpieces according to color and shape. The tool is equipped with an ESP 32 Cam module for reading blue and green workpieces. In addition, this machine is also equipped with a solenoid ejector as a pusher of the workpiece from the reservoir to the storage area for the sorted results. Tests to determine the effect of input and output processes and the performance and function of SCADA as a monitoring and controlling system for the sorting machine process have been carried out. As a result, SCADA can function properly to monitor and control the candy sorting machine process. This is evidenced by the connection of all SCADA equipment, PLC outseal, and sorting machine hardware.
\end{abstract}

Keywords: Image Processing, ESP 32 Cam, PLC Outseal, SCADA Vijeo Citect, Sorting Machine.

\section{ABSTRAK}

Pada perkembangan proses produksi di era revolusi industri 4.0 ini, kecepatan, ketepatan, konsistensi, dan ketelitian sangat dibutuhkan. Oleh karena itu dibutuhkan sebuah sistem yang dapat mengawasi, mengontrol, dan mengakuisisi data-data yang dibutuhkan dari suatu proses produksi, sistem ini disebut SCADA. Pada artikel ini, dibuat pemrograman SCADA dengan software Vijeo Citect untuk memantau dan mengontrol mesin sortir bungkus permen berbasis image processing. Mesin sortir berbasis image processing ini berfungsi untuk menyortir benda kerja sesuai dengan warna dan bentuk. Alat ini dilengkapi dengan modul ESP 32 Cam untuk membaca benda kerja biru dan hijau. selain itu, mesin ini juga dilengkapi solenoid ejector sebagai pendorong benda kerja dari penampungan ke tempat penyimpanan hasil sortir. Pengujian untuk mengetahui pengaruh input dan output proses dan kinerja serta fungsi SCADA sebagai sebuah sistem pemntauan dan pengendali proses mesin sortir telah dilakukan. Hasilnya SCADA dapat berfungsi dengan baik untuk memantau dan mengontrol proses mesin sortir permen. Hal ini dibuktikan dengan terhubungnya semua peralatan SCADA, PLC outseal, dan hardware mesin sortir.

Kata kunci: Image Processing, ESP 32 Cam, PLC Outseal, SCADA Vijeo Citect, mesin sortir

\section{PENDAHULUAN}

Di era perkembangan proses produksi pada revolusi industri 4.0 ini, kecepatan, ketepatan, konsistensi, dan ketelitian, sangat dibutuhkan. Perusahaan menginginkan proses produksi dapat dimonitor secara real time dan semua kejadian dalam proses terekam untuk keperluan Analisa proses. Oleh karena itu diperlukan suatu sistem yang bisa memberikan solusi untuk mencapai keinginan perusahaan. Salah satu solusinya 
adalah menggunakan software SCADA (Supervisory Control and Data Acquisition). Arsitektur SCADA terdiri dari Operator, HMI (Human Machine Interface), MTU (Master Terminal Unit), PLC (Programmable Logic Controller), Sistem Komunikasi, dan Plant device [1],[2].

Arsitektur SCADA diterapkan pada mesin sortir bungkus permen berbasis image processing agar kinerja proses produksinya dapat terpantau dengan baik. Pemantauan proses mensortir bungkus permen penting dilakukan untuk memilah warna bungkus permen sehingga tidak salah penempatannya dan mengurangi hasil produksi yang cacat.

Sensor yang digunakan pada mesin sortir ini adalah sensor kamera ESP Cam. Proses pengolahan datanya menggunakan proses image processing. Data hasil pengolahan gambar diteruskan ke PLC untuk ditampilkan di SCADA dan PLC dapat menggerakkan solenoid ejector untuk mendorong bungkus permen sesuai warna dan penempatannya. Mesin sortir bungkus permen dirancang dalam bentuk miniatur yang merupakan replika mesin-mesin industri. Namun peralatan atau komponen yang digunakan masih skala laboratorium belum skala industri. Mesin sortir telah banyak dibuat oleh para peneliti antara lain mesin sortir barang otomatis yang menggunakan Arduino [3]-[5] mesin sortir ikan berdasarkan berat berbasis CNC [6], mesin sortir biji kopi berdasarkan getaran [7] dan fuzzy logic [8], mesin sortir sampah berbasiskan CNC [9], [10].

Dari berbagai literatur tersebut belum ada yang merancang bangun mesin sortir bungkus permen yang menggunakan image processing dan dimonitoring prosesnya melalui SCADA. Sehingga pada penelitian ini kami membuat mesin sortir bungkus permen ini dengan inovasi adanya sensor kamera dan monitoring via SCADA. Kinerja mesin sortir bungkus permen ini dianalisis dan hasilnya disajikan pada artikel penelitian ini. Pengujian dilakukan secara bertahap mulai dari koneksi komunikasi PLCSCADA sampai running program PLC-SCADA. Kinerja yang dihasilkan oleh mesin sortir bungkus permen sangat baik meskipun masih ada error pada saat pembacaan data melalui kamera.

\section{METODE PENELITIAN}

Metode penelitian yang dilakukan adalah metode eksperimen. Tahapan penelitian dimulai dari:

1. Perancangan mesin sortir bungkus permen yang terdiri dari pemilihan spesifikasi, peletakan komponen, dan wiring diagram.
2. Pembuatan hardware mesin sortir bungkus permen

3. Pembuatan program PLC outseal

4. Pembuatan program SCADA

5. Koneksi PLC-SCADA

6. Running program PLC-SCADA

7. Pengujian system

8. Analisa system ini adalah:

Pengujian yang dilakukan pada penelitian

1. Pengujian komunikasi antara PLC (Programmable Logic Controller) dan SCADA dengan cara menghubungkan PLC dan laptop yang sudah ter-install SCADA dengan kabel RS-232.

2. Pengujian sistem SCADA pada mode operasi manual, yaitu dengan cara melihat tampilan input dan output pada keadaan real dan pada tampilan SCADA, kemudian melihat tampilan alarm yang sudah dibuat di SCADA.

3. Pengujian sistem SCADA pada mode operasi auto, pemgujian ini dilakukan dengan cara menjalankan mesin sortir pada mode auto, kemudian benda kerja yang diletakkan pada tempat penampungan adalah benda kerja biru, hijau, reject, dan acak (benda kerja biru, hijau, dan reject) dimasukkan secara acak, pengujian untuk setiap masing-masing benda kerja dilakukan sebanyak 20 kali.

\section{HASIL DAN PEMBAHASAN \\ a. Pengujian komunikasi antara PLC dan SCADA}

Pengujian komunikasi antara PLC dan SCADA bertujuan untuk mengetahui apakah PLC dan SCADA sudah terhubung. Keberhasilan pengujian terlihat dari tidak adanya titik-titik dalam display SCADA dan tidak ada alarm seperti pada Gambar 1.

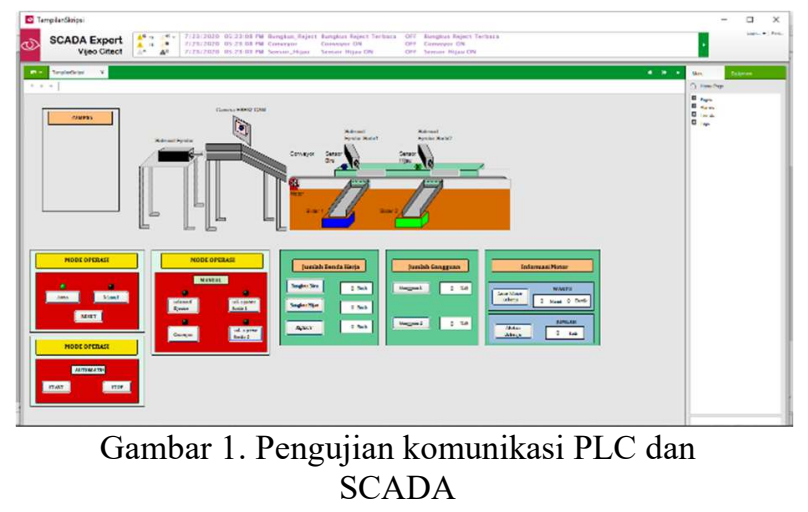




\section{Kinerja Pemantauan Proses Mesin Sortir Bungkus Permen}

Dari gambar 1, yaitu pada pengujian pertama terhadap komunikasi PLC dan SCADA, dapat dilihat bahwa komunikasi antara PLC dan SCADA yang dihubungkan dengan kabel RS-232 terhubung dengan baik.

\section{b. Pengujian sistem SCADA pada mode operasi manual}

Pengujuan mode operasi manual bertujuan untuk memastikan setiap komponen berfungsi dengan baik. Ketika sensor mendeteksi benda berwarna biru maka kamera akan membaca warna biru dan mengaktifkan relay biru sperti terlihat pada Gambar 2.

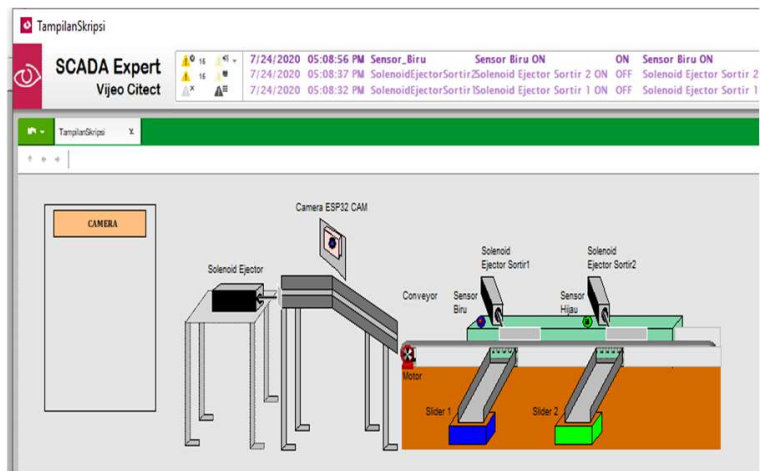

Gambar 2. Tampilan SCADA setelah dilakukan pengujian pada sensor 1 (Biru)

Gambar 2 adalah tampilan dari sistem SCADA yang sudah dilakukan pengujian terhadap sensor biru, dari gambar 2 dapat dilihat bahwa alarm untuk sensor biru bekerja sesuai dengan deskripsi kerja.

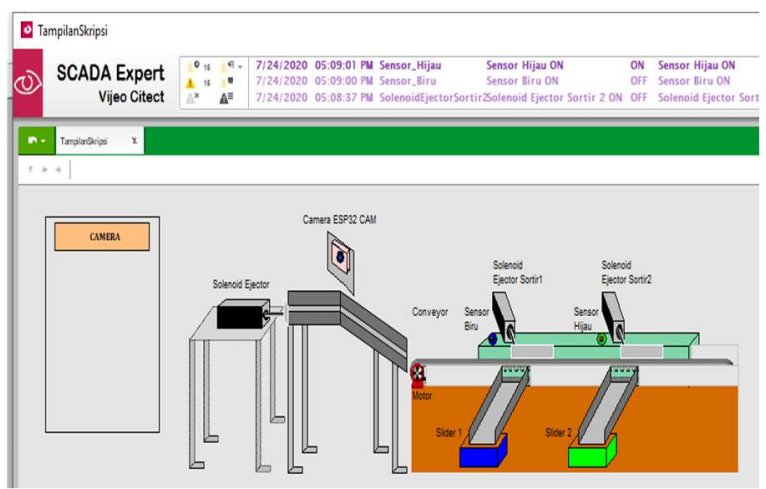

Gambar 3. Tampilan SCADA setelah dilakukan pengujian pada sensor 2 (Hijau)

Gambar 3 adalah tampilan dari sistem SCADA yang sudah dilakukan pengujian terhadap sensor hijau, dari gambar 3 dapat dilihat bahwa alarm untuk sensor hijau bekerja sesuai dengan deskripsi kerja.

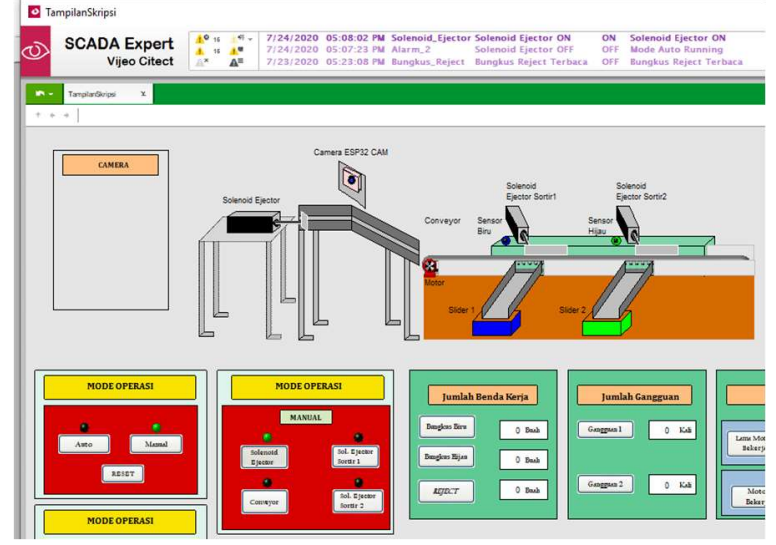

Gambar 4. Tampilan SCADA setelah dilakukan pengujian pada solenoid ejector

Gambar 4 adalah tampilan dari sistem SCADA yang sudah dilakukan pengujian terhadap solenoid ejector, dari gambar 4 dapat dilihat bahwa alarm untuk solenoid ejector bekerja sesuai dengan deskripsi kerja.

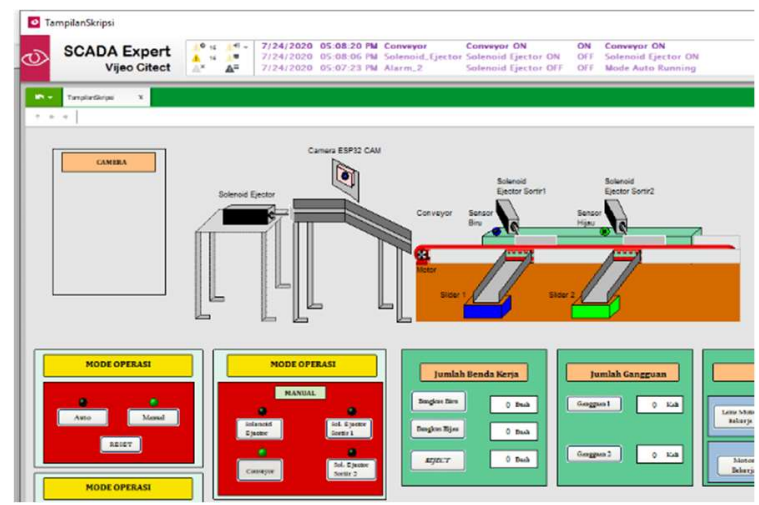

Gambar 5. Tampilan SCADA setelah dilakukan pengujian pada conveyor

Gambar 5 adalah tampilan dari sistem SCADA yang sudah dilakukan pengujian terhadap conveyor, dari gambar 5 dapat dilihat bahwa alarm untuk conveyor bekerja sesuai dengan deskripsi kerja.

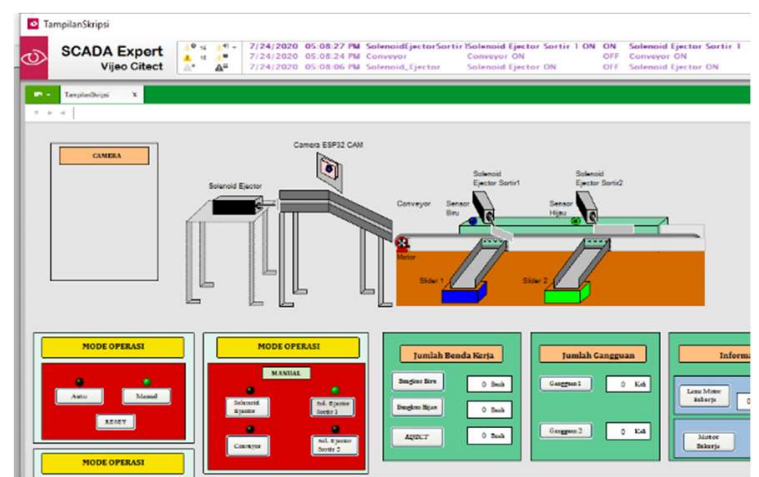

Gambar 6. Tampilan SCADA setelah dilakukan pengujian pada solenoid ejector sortir 1 


\section{Kinerja Pemantauan Proses Mesin Sortir Bungkus Permen .........}

Gambar 6 adalah tampilan dari sistem SCADA yang sudah dilakukan pengujian terhadap solenoid ejector sortir 1, dari gambar 6 dapat dilihat bahwa alarm untuk solenoid ejector sortir 1 bekerja sesuai dengan deskripsi kerja.

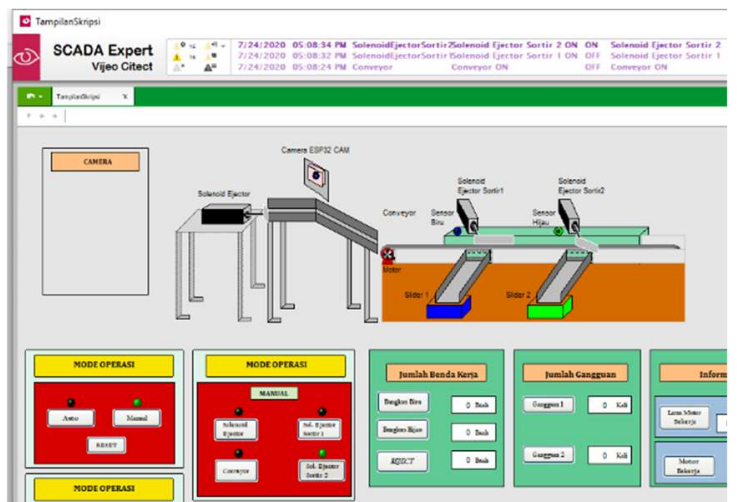

Gambar 7. Tampilan SCADA setelah dilakukan pengujian pada solenoid ejector sortir 2

Gambar 7 adalah tampilan dari sistem SCADA yang sudah dilakukan pengujian terhadap solenoid ejector sortir 2, dari gambar 7 dapat dilihat bahwa alarm untuk solenoid ejector sortir 2 bekerja sesuai dengan deskripsi kerja.

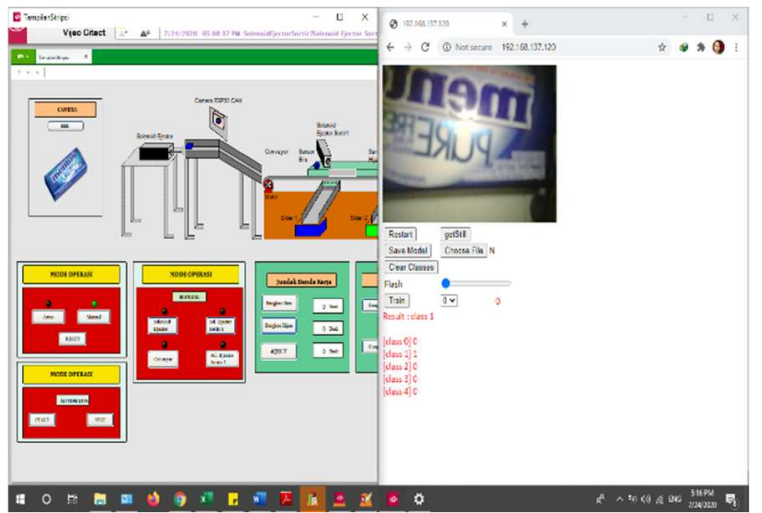

Gambar 8. Tampilan SCADA setelah dilakukan pengujian pada dengan ESP 32Cam dan SCADA pada bungkus biru

Gambar 8 adalah tampilan dari sistem SCADA yang sudah dilakukan pengujian terhadap benda kerja biru, dari gambar 8 dapat dilihat bahwa alarm untuk benda kerja biru bekerja sesuai dengan deskripsi kerja.

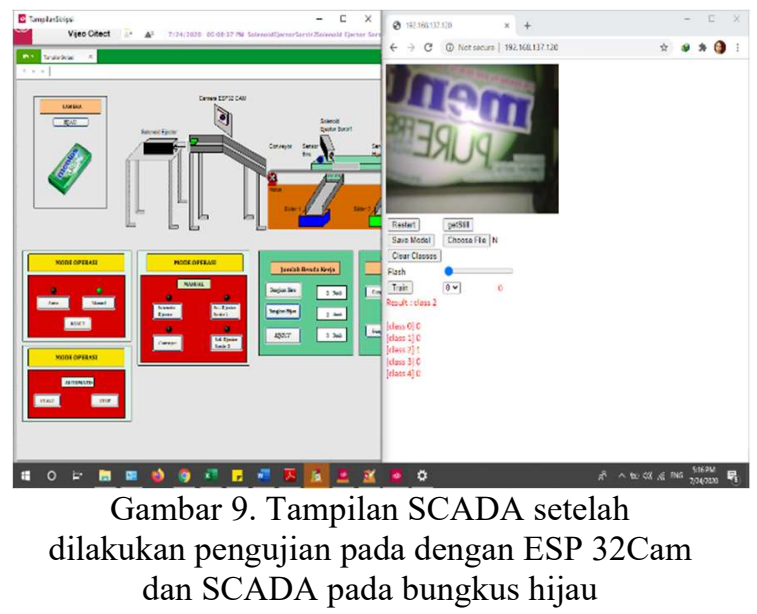

Gambar 9 adalah tampilan dari sistem SCADA yang sudah dilakukan pengujian terhadap benda kerja hijau, dari gambar 9 dapat dilihat bahwa alarm untuk benda kerja hijau bekerja sesuai dengan deskripsi kerja.

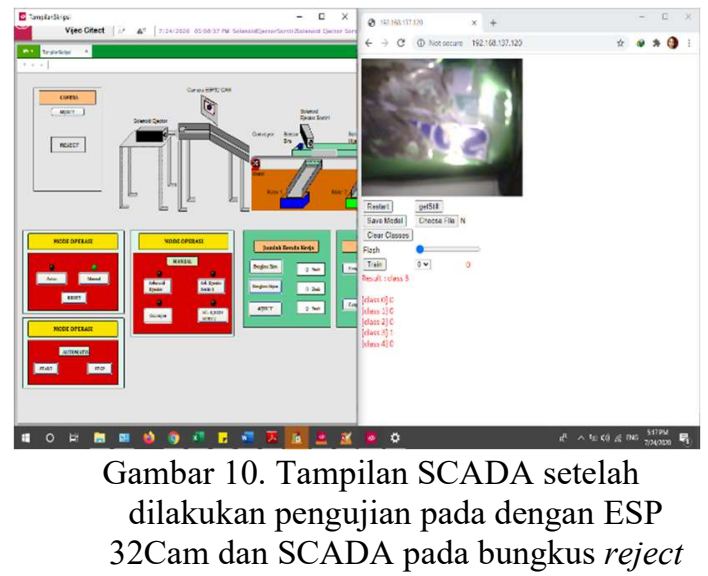

Gambar 10 adalah tampilan dari sistem SCADA yang sudah dilakukan pengujian terhadap benda kerja reject, dari gambar 10 dapat dilihat bahwa alarm untuk benda kerja reject bekerja sesuai dengan deskripsi kerja.

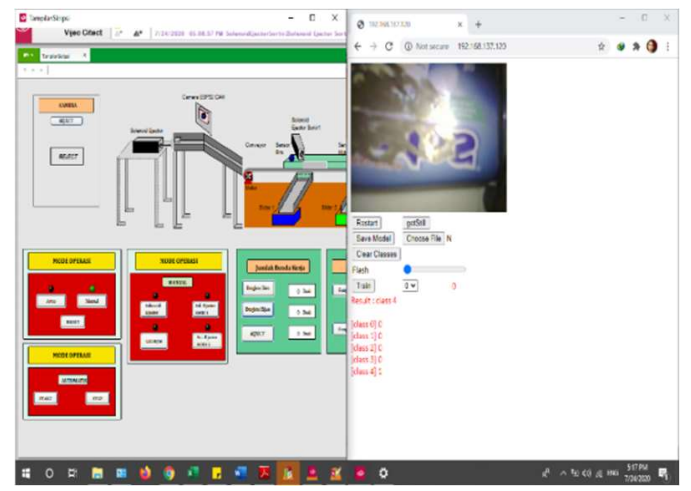

Gambar 11. Tampilan SCADA setelah dilakukan pengujian pada dengan ESP 32Cam dan SCADA pada bungkus reject 


\section{Kinerja Pemantauan Proses Mesin Sortir Bungkus Permen .........}

Gambar 11 adalah tampilan dari sistem SCADA yang sudah dilakukan pengujian terhadap benda kerja reject, dari gambar 11 dapat dilihat bahwa alarm untuk benda kerja reject bekerja sesuai dengan deskripsi kerja.

Tabel 1. Tabel pengujian input dan output pada mode operasi manual

\begin{tabular}{ccccc}
\hline $\begin{array}{c}\text { No. } \\
\text { Pengujian }\end{array}$ & Objek Pengujian & Real & SCADA & Keterangan \\
\hline 1 & Sensor Biru (S.1) & Aktif & Aktif & Berhasil \\
\hline 2 & Sensor Hijau (S.2) & Aktif & Aktif & Berhasil \\
\hline 3 & Solenoid Ejector & Aktif & Aktif & Berhasil \\
\hline 4 & Conveyor & Aktif & Aktif & Berhasil \\
\hline 5 & Solenoid Ejector Sortir 1 & Aktif & Aktif & Berhasil \\
\hline 6 & Solenoid Ejector Sortir 2 & Aktif & Aktif & Berhasil \\
\hline 7 & Bungkus Biru & Bungkus Biru & Bungkus Biru & Berhasil \\
\hline 8 & Bungkus Hijau & Bungkus Hijau & Bungkus Hijau & Berhasil \\
\hline 9 & Reject Biru & Reject Biru & Reject Biru & Berhasil \\
\hline 10 & Reject Hijau & Reject Hijau & Reject Hijau & Berhasil \\
\hline & & & &
\end{tabular}

Dari tabel 1, dapat dilihat bahwa pengujian yang dilakukan terhadap input dan output dari prototipe mesin sortir menunjukkan bahwa input dan output pada keadaan real dan pada tampilan SCADA bekerja sesuai dengan deskripsi sistem kerja yang diinginkan.

\section{c. Pengujian sistem SCADA pada mode operasi out}

Pengujian mode operasi out bertujuan untuk melihat kinerja output dari masing-masing komponen. Hasil pengujian terlihat pada Tabel 2.

Tabel 2. Tabel pengujian mode operasi auto pada benda kerja biru

\begin{tabular}{|c|c|c|c|c|}
\hline $\begin{array}{c}\text { No. } \\
\text { Pengujian }\end{array}$ & Objek Pengujian & $\begin{array}{l}\text { Kesalahan } \\
\text { Pembacaan }\end{array}$ & Gangguan & Keterangan \\
\hline 1 & Benda kerja biru & Tidak & Tidak & Berhasil \\
\hline 2 & Benda kerja biru & Tidak & Tidak & Berhasil \\
\hline 3 & Benda kerja biru & Tidak & Tidak & Berhasil \\
\hline 4 & Benda kerja biru & Tidak & Gangguan 2 & $\begin{array}{l}\text { Sensor tidak mendeteksi adanya } \\
\text { benda kerja pada conveyor, maki } \\
\text { conveyor berhenti bekeria }\end{array}$ \\
\hline 5 & Benda kerja biru & Tidak & Tidak & Berhasil \\
\hline 6 & Benda kerja biru & Tidak & Tidak & Berhasail \\
\hline 7 & Benda kerja biru & Tidak & Tidak & Berhasil \\
\hline 8 & Benda kerja biru & Tidak & Tidak & Berhasil \\
\hline 9 & Benda kerja biru & Tidak & Tidak & Berhasil \\
\hline 10 & Benda kerja biru & Tidak & Tidak & Berhasil \\
\hline 11 & Benda kerja biru & Reject & Tidak & Berhasil \\
\hline 12 & Benda kerja biru & Tidak & Gangguan 2 & $\begin{array}{l}\text { Sensor tidak mendeteksi adanya } \\
\text { benda kerja pada conveyor, maki } \\
\text { conveyor berhenti bekeria }\end{array}$ \\
\hline 13 & Benda kerja biru & Tidak & Gangguan 1 & $\begin{array}{c}\text { Benda keria pada penampungan } \\
\text { tidak terdorog }\end{array}$ \\
\hline 14 & Benda kerja biru & Tidak & Tidak & Berhasil \\
\hline 15 & Benda kerja biru & Tidak & Tidak & Berhasil \\
\hline 16 & Benda kerja biru & Tidak & Tidak & Berhasil \\
\hline 17 & Benda kerja biru & Tidak & Tidak & Berhasil \\
\hline 18 & Benda kerja biru & Tidak & Gangguan 2 & $\begin{array}{l}\text { Sensor tidak mendeteksi adanya } \\
\text { benda kerja pada conveyor, maks } \\
\text { conveyor berhenti bekerja }\end{array}$ \\
\hline 19 & Benda kerja biru & Tidak & Tidak & Berhasil \\
\hline 20 & Benda kerja biru & Tidak & Tidak & Berhasil \\
\hline
\end{tabular}

Dari Tabel 2 dapat dilihat bahwa pada percobaan pertama yang dilakukan sebanyak 20 kali pada benda kerja biru adalah keberhasilan yang didapat adalah sebanyak 15 kali dan kegagalan sebanyak 5 kali, kegagalan pada percobaan pertama terjadi karena adanya gangguan mekanik pada mesin sortir, gangguan yang terjadi pada pengujian ini adalah gangguan 1 dan gangguan 2, gangguan 1 dan 2 terjadi pada nomor pengujian ke-4, ke-12, ke-13, dan ke-18. Gangguan 1 terjadi karena solenoid ejector pada penampungan tidak berhasil mendorong benda kerja pada penampungan, gangguan 2 terjadi karena sensor biru tidak mendeteksi adanya benda kerja pada conveyor, maka conveyor akan berhenti bekera, dan pada percobaan pertama juga terjadi kesalahan pembacaan pada nomor pengujian ke-11 dimana seharusnya ESP 32Cam membaca benda kerja biru tetapi yang terbaca oleh ESP 32Cam adalah benda kerja reject.

Tabel 3. Tabel pengujian mode operasi auto pada benda kerja hijau

\begin{tabular}{|c|c|c|c|c|}
\hline $\begin{array}{c}\text { No. } \\
\text { Penguiian }\end{array}$ & Qbjek Pengujian & $\begin{array}{l}\text { Kesalahan } \\
\text { Pembacaan. }\end{array}$ & Gangguan & Keterangan \\
\hline 1 & Benda keria bijau & Jidak & Gangguan 1 & $\begin{array}{c}\text { Benda kecia qada penamoungan } \\
\text { tidak terdorog }\end{array}$ \\
\hline 2 & Benda keria hiiau & Tidak & Tidak & Berhasil \\
\hline 3 & Benda keria hilau & Tidak & Tidak & Berhasil \\
\hline 4 & Benda keria bijau & Iidak & Tidak & Berchasil \\
\hline 5 & Benda keria bilau & Tidak & Tidak & Berhasil \\
\hline 6 & Benda keria hijau & Tidak & Tidak & Berhasil \\
\hline 7 & Benda keria bijau & Tidak & Gangguan 2 & $\begin{array}{c}\text { Sensor tidak mendeteksi adanxa } \\
\text { benda keria Qada conveyor, maka } \\
\text { conveyor berhenti bekeria. }\end{array}$ \\
\hline 8 & Benda keria bijau & Iidak & Tidak & Bechasil \\
\hline 9 & Benda keria hijau & Tidak & Tidak & Berhasil \\
\hline 10 & Benda keria biiau & Tidak & Tidak & Berhasil \\
\hline 11 & Benda keria hilau & Tidak & Tidak & Berhasil \\
\hline 12 & Benda keria hiiau & Tidak & Tidak & Berhasil \\
\hline 13 & Benda keria bijau & Tidak & Gangguan 2 & $\begin{array}{l}\text { Sensor tidak mendeteksi adanxa } \\
\text { benda keria pada conveyor, maka } \\
\text { conveyor berhenti bekeria. }\end{array}$ \\
\hline 14 & Benda keria bijau & Tidak & Gangguan 2 & $\begin{array}{l}\text { Sensor tidak mendeteksi adanxa. } \\
\text { benda keria pada conveyor, maaka } \\
\text { conveyor berhenti bekeria. }\end{array}$ \\
\hline 15 & Benda keria hiiau & Tidak & Tidak & Berhasil \\
\hline 16 & Benda keria bijau. & Iidak & Gangguan 1 & $\begin{array}{c}\text { Benda kecia pada penampungan } \\
\text { tidak terdorog }\end{array}$ \\
\hline 17 & Benda keria hijau & Tidak & Tidak & Berhasil \\
\hline 18 & Benda keria biiau & Tidak & Tidak & Berhasil \\
\hline 19 & Benda keria hilau & Tidak & Tidak & Berhasil \\
\hline 20 & Benda keria hilau & Tidak & Tidak & Berhasil \\
\hline
\end{tabular}

Dari Tabel 3 dapat dilihat bahwa pada percobaan kedua yang dilakukan sebanyak 20 kali pada benda kerja hijau adalah keberhasilan yang didapat adalah sebanyak 15 kali dan kegagalan sebanyak 5 kali, kegagalan pada percobaan kedua terjadi karena adanya gangguan mekanik pada mesin sortir, gangguan yang terjadi pada pengujian ini adalah gangguan 1 dan gangguan 2 , gangguan 1 dan 2 terjadi pada nomor pengujian ke-1, ke-7, ke-13, ke-14, dan ke-16. Gangguan 1 terjadi karena solenoid ejector pada penampungan tidak berhasil mendorong benda kerja pada penampungan dan gangguan 2 terjadi karena sensor biru tidak mendeteksi adanya benda kerja pada conveyor, maka conveyor akan berhenti bekerja. 


\section{Kinerja Pemantauan Proses Mesin Sortir Bungkus Permen .........}

Tabel 4. Tabel pengujian mode operasi auto pada benda kerja reject

\begin{tabular}{|c|c|c|c|c|}
\hline $\begin{array}{c}\text { No. } \\
\text { Penguiian }\end{array}$ & Objek Pengujian & $\begin{array}{l}\text { Kesalahan } \\
\text { Pembacaan }\end{array}$ & Gangguan & Keterangan \\
\hline 1 & Benda keria reject & Tidak & Tidak & Berhasil \\
\hline 2 & Benda keria reject & Biru & Tidak & Gagal \\
\hline 3 & Benda keriag reject & Jidak & Gangguan 1 & $\begin{array}{l}\text { Benda keria pada penampungar } \\
\text { tidak terdorog }\end{array}$ \\
\hline 4 & Benda keria reject & Tidak & Tidak & Berchasil \\
\hline 5 & Benda keria reject & Tidak & Tidak & Berhasil \\
\hline 6 & Benda keria reject & Jidak & Gangguan 2 & $\begin{array}{l}\text { Sensor tidak mendeteksi adanox } \\
\text { benda keria bada conveyor, mak } \\
\text { conveyor berhenti bekeria. }\end{array}$ \\
\hline 7 & Benda keria reject & Tidak & Gangguan 2 & $\begin{array}{l}\text { Sensor tidak mendeteksi adanox } \\
\text { benda keria pada conveyor, mak } \\
\text { conveyor berhenti bekeria }\end{array}$ \\
\hline 8 & Benda keria reject & Tidak & Tidak & Berhasil \\
\hline 9 & Benda keria reject & Tidak & Tidak & Berhasil \\
\hline 10 & Benda kerią reject & Biru & Tidak & Gagal \\
\hline 11 & Benda kecia reject & Tidak & Gangguan 2 & $\begin{array}{l}\text { Sensor tidak mendeteksi adaoya } \\
\text { benda keria pada conveyor, mak } \\
\text { conveyor berhenti bekeria }\end{array}$ \\
\hline 12 & Benda keria reject & Jidak & Gangguan 1 & $\begin{array}{c}\text { Benda keria pada penamanpungar } \\
\text { tidak terdorog }\end{array}$ \\
\hline 13 & Benda keria reject & Tidak & Tidak & Berhasil \\
\hline 14 & Benda keria reject & Biru & Tidak & Gagal \\
\hline 15 & Benda keria reject & Tidak & Tidak & Berhasil \\
\hline 16 & Benda keria reject & Iidak & Tidak & Berchasil \\
\hline 17 & Benda keria reject & Iidak & Tidak & Berhasil \\
\hline 18 & Benda keria reject & Iidak & Tidak & Berhasil \\
\hline 19 & Benda keria reject & Iidak & Tidak & Berhasil \\
\hline 20 & Benda keria reject & Tidak & Tidak & Berhasil \\
\hline
\end{tabular}

Dari Tabel 4 dapat dilihat bahwa pada percobaan ketiga yang dilakukan sebanyak 20 kali pada benda kerja reject adalah keberhasilan yang didapat adalah sebanyak 13 kali dan kegagalan sebanyak 7 kali, kegagalan pada percobaan ketiga terjadi karena adanya gangguan mekanik pada mesin sortir, gangguan yang terjadi pada pengujian ini adalah gangguan 1 dan gangguan 2 , gangguan 1 dan 2 terjadi pada nomor pengujian ke-3, ke-6, ke-11, dan ke-12. Gangguan 1 terjadi karena solenoid ejector pada penampungan tidak berhasil mendorong benda kerja pada penampungan, gangguan 2 terjadi karena sensor biru tidak mendeteksi adanya benda kerja pada conveyor, maka conveyor berhenti bekerja, dan terjadi kesalahan pembacaan pada nomor pengujian ke-2, ke-10, dan ke-14 dimana seharusnya ESP 32Cam membaca benda kerja reject tetapi yang terbaca oleh ESP 32Cam adalah benda kerja biru.

Dari Tabel 5 dapat dilihat bahwa pada percobaan keempat yang dilakukan sebanyak 20 kali pada benda kerja acak adalah keberhasilan yang didapat adalah sebanyak 13 kali dan kegagalan sebanyak 7 kali, kegagalan terjadi karena adanya gangguan mekanik pada mesin sortir, gangguan yang terjadi pada pengujian ini adalah gangguan 1 dan gangguan 2, gangguan 1 dan 2 terjadi pada nomor pengujian ke-4, ke-10, ke-14, ke-15, ke-18, ke-19, dan ke-20. Gangguan 1 terjadi karena solenoid ejector pada penampungan tidak berhasil mendorong benda kerja pada penampungan, gangguan 2 terjadi karena sensor biru tidak mendeteksi adanya benda kerja pada conveyor, maka conveyor akan berhenti bekerja

Tabel 5. Tabel pengujian mode operasi auto pada benda kerja acak

\begin{tabular}{|c|c|c|c|c|}
\hline $\begin{array}{c}\text { No. } \\
\text { Penguiam }\end{array}$ & Objek Pengujian & $\begin{array}{l}\text { Kesalahan } \\
\text { Pembacaan }\end{array}$ & Gangguan & Keterangan \\
\hline 1 & Benda keria biru & Tidak & Tidak & Berhasil \\
\hline 2 & Benda keria reject & Tidak & Tidak & Berhasil \\
\hline 3 & Benda keria reject & Tidak & Tidak & Berhasil \\
\hline 4 & Benda keria bijau. & Tidak & Ganggyan 2 & $\begin{array}{c}\text { Sensor tidak mendetekssi adanova } \\
\text { bedda kecia pada conveyor, maka } \\
\text { conveyor berhenti bekeria }\end{array}$ \\
\hline 5 & Benda kecia bijay & Tidak & Iidak & Berhasil \\
\hline 6 & Benda keria reject & Tidak. & Tidak. & Berhasil \\
\hline 7 & Benda kerja biru & Iidak & Iidak & Berhasil \\
\hline 8 & Benda kerià reject & Tidak & Tidak & Berhasil \\
\hline 9 & Benda kerja reject & Iidak. & Tidak. & Berhasil \\
\hline 10 & Benda kerda reject & Iidak & Gangeguan 2 & $\begin{array}{c}\text { Sensor tidak mendeteksi adanova } \\
\text { benda keria pada conveyor, maka } \\
\text { conveyor berhenti bekeria. }\end{array}$ \\
\hline 11 & Benda keria hiliau & Tidak. & Tidak. & Berhasil \\
\hline 12 & Benda keria biru & Tidak & Tidak & Berhasil \\
\hline 13 & Benda keria hijau & Iidak. & Tidak. & Berhasil \\
\hline 14 & Benda keria birc & Tidak & Gangguan 2 & $\begin{array}{l}\text { Sensor tidak mendeteksi adanova } \\
\text { benda keria pada conveyor, maka } \\
\text { conveyor berhenti bekeria. }\end{array}$ \\
\hline 15 & Benda kerda reject & Tidak & Gangayan 2 & $\begin{array}{l}\text { Sensor tidak mendeteksia adanova } \\
\text { benda keria pada conveyor, maka } \\
\text { conveyor berhenti bekeria. }\end{array}$ \\
\hline 16 & Benda keria reject & Iidak. & Iidak. & Berhasil \\
\hline 17 & Benda kerja biru & Iidak & Tidak & Berhasil \\
\hline 18 & Benda kercia reject & Tidak & Gangguaa 1 & $\begin{array}{l}\text { Benda kecia . pada penampungan } \\
\text { tidak terderang }\end{array}$ \\
\hline 19 & Benda keria reject & Tidak & Gangeguan 2 & $\begin{array}{l}\text { Sensor tidak mendeteksi adanva } \\
\text { benda keria pada conveyor, maka } \\
\text { conveyor berhenti bekeria. }\end{array}$ \\
\hline 20 & Benda kecia bijau. & Tidak & Ganggryan 1 & $\begin{array}{l}\text { Benda kecia pada penampungan } \\
\text { tidak terdorang }\end{array}$ \\
\hline
\end{tabular}

\section{KESIMPULAN}

Kesimpulan yang didapat dari hasil penelitian ini adalah, komunikasi PLC dan SCADA terhubung dengan baik, pemrograman sistem SCADA yang dibuat bekerja sesuai dengan deskripsi yang diinginkan, keterlambatan pembacaan sensor biru dan hijau berpengaruh terhadap tampilan alarm SCADA, dan posisi kamera yang kurang ideal membuat pembacaan benda kerja pada ESP 32Cam tidak sesuai dengan benda kerja yang ada pada penampungan.

\section{DAFTAR PUSTAKA}

[1] M. Dwiyaniti, "Dasar-dasar Pemrograman SCADA dengan Software Vijeo Citect," Depok Politek. Negeri Jakarta, 2019.

[2] Bailey, D., \& Wright, E. 2003. Practical SCADA for industry. Elsevier

[3] M. Eriyadi and I. F. Fauzian, "Desain Prototipe Mesin Sortir Barang Otomatis," JTERA (Jurnal Teknol. Rekayasa), vol. 4, no. 2, p. 147, 2019.

[4] Arijaya, I. M. N. (2019). Rancang Bangun Alat Konveyor Untuk Sistem Soltir Barang Berbasis Mikrokontroler Arduino Uno. Jurnal RESISTOR (Rekayasa Sistem Komputer), 2(2), 126-135 
[5] P. Pujono, I. M. Prasetia, and A. F. Santoso, "Rancang Bangun Mesin Sortir Ikan Berdasarkan Berat Dengan Mekanisme Pergerakan Konveyor," Bangun Rekaprima Maj. Ilm. Pengemb. Rekayasa, Sos. dan Hum., vol. 5, no. 2, Oktober, pp. 9-18, 2019.

[6] Z. Zulfikar, I. Mawardi, and M. Mawardi, "Pembuatan Mesin Sortir Biji Kopi Menggunakan Mekanisme Getar Dengan Daya 1 HP," J. Mesin Sains Terap., vol. 3, no. 1, pp. 28-30, 2019.

[7] Irawan, Diyan, and Djoko Wahyudi. " Perancangan dan Pembuatan Alat Penyortir Barang Otomatis Berdasarkan Warna Berbasis Arduino Uno." Energy-Jurnal Ilmiah Ilmu-Ilmu Teknik 3.2. 2013.

[8] E. Ramadhan, "Perancangan dan Implementasi Mesin Sortir Biji Kopi Otomatis Menggunakan Fuzzy Logic Controller." Universitas Multimedia Nusantara, 2020.

[9] P. Pujono, A. Setiawan, and D. Prabowo, "Rancang Bangun Mekanisme Pergerakan Conveyor Pada Mesin Sortir Sampah Kaleng Dan Botol Plastik," Bangun Rekaprima Maj. Ilm. Pengemb. Rekayasa, Sos. dan Hum., vol. 6, no. 2, Oktober, pp. 113, 2020.

[10] Y. N. Dian, "Perancangan Mesin Centrifugal Untuk Optimalisasi Tenaga Sortir Sampah Plastik," J. Appl. Mech. Eng. Renew. Energy, vol. 1, no. 1, pp. 1-5, 2020. 